\title{
Macroscopic Observation of Soil Nitrification Kinetics Impacted by Copper Nanoparticles: Implications for Micronutrient Nanofertilizer
}

\author{
Allison Rick VandeVoort ${ }^{1}$ and Yuji Arai ${ }^{2, *}$ \\ 1 Department of Biological and Environmental Sciences, Georgia College \& State University, Campus Box 081, \\ Milledgeville, GA 31061, USA; allison.vandevoort@gcsu.edu \\ 2 Department of Natural Resources and Environmental Sciences, University of Illinois at Urbana-Champaign, \\ Urbana, IL 61801, USA \\ * Correspondence: yarai@illinois.edu; Tel.: +1-217-244-3602
}

Received: 2 October 2018; Accepted: 3 November 2018; Published: 8 November 2018

\begin{abstract}
The potential agricultural use of metal nanoparticles (NPs) for slow-release micronutrient fertilizers is beginning to be investigated by both industry and regulatory agencies. However, the impact of such NPs on soil biogeochemical cycles is not clearly understood. In this study, the impact of commercially-available copper NPs on soil nitrification kinetics was investigated via batch experiments. The $\mathrm{X}$-ray absorption near edge structure spectroscopy analysis showed that the NPs readily oxidized to $\mathrm{Cu}(\mathrm{II})$ and were strongly retained in soils with minimum dissolution $(<1 \%$ of total mass). The $\mathrm{Cu}^{2+}$ (aq) at $1 \mathrm{mg} / \mathrm{L}$ showed a beneficial effect on the nitrification similar to the control: an approximately $9 \%$ increase in the average rate of nitrification kinetics $\left(V_{\max }\right)$. However $V_{\text {max }}$ was negatively impacted by ionic $\mathrm{Cu}$ at 10 to $100 \mathrm{mg} / \mathrm{L}$ and $\mathrm{CuNP}$ at 1 to $100 \mathrm{mg} / \mathrm{L}$. The copper toxicity of soil nitrifiers seems to be critical in the soil nitrification processes. In the CuNP treatment, the suppressed nitrification kinetics was observed at 1 to $100 \mathrm{mg} / \mathrm{kg}$ and the effect was concentration dependent at $\geq 10 \mathrm{mg} / \mathrm{L}$. The reaction products as the results of surface oxidation such as the release of ionic $\mathrm{Cu}$ seem to play an important role in suppressing the nitrification process. Considering the potential use of copper NPs as a slow-release micronutrient fertilizer, further studies are needed in heterogeneous soil systems.
\end{abstract}

Keywords: copper nanoparticles; nanofertilizer; soil; nitrification; nitrification kinetics; toxicity

\section{Introduction}

With the rise of nanotechnology within the past decade, nanofertilizers have been considered for use in agricultural fields [1]. While this technology continues to advance, the possibility for slow-release micronutrients resulting from the nanosized solid state of these products is appealing for some agricultural systems. In particular, hydrological regimes impacted by climate change could alter the mobility of micronutrients, influencing the plant growth and microbially-mediated biochemical cycles of nutrients (e.g., $\mathrm{N}$ and $\mathrm{P}$ ). The advent of nanotechnology could increase the feasibility of the long desired agricultural goal of slow-release fertilizers, which are both more cost-efficient and environmentally sound $[2,3]$. The physical state of nanoparticles (NPs) as nanosized solid metal rather than dissolved ions has the potential to allow for a controlled release over time in soil solutions. Trace metals such as $\mathrm{Cu}$ and $\mathrm{Zn}$, essential micronutrients for crops and microbial growth [4], are commonly produced NPs. Like many micronutrients, these metal-based NPs have the potential to be beneficial to plants and/or microorganisms by preventing deficiency; however, an overdose of metal NPs can lead to toxicity. Benefits of metallic $\mathrm{Cu}(0) \mathrm{NPs}$ (CuNPs) to plants include increased shoot: root ratio in lettuce seedlings [5]. However, CuNPs can cause unique adverse reactions in plants not accounted for 
by ionic copper. For instance, seedlings of mung beans and wheat grown on a CuNP-impregnated agar exhibited diminished root and shoot length beginning at concentrations of $200 \mathrm{mg} / \mathrm{L}$ [6]. Metallic CuNPs are known to cause less oxidative stress on plants than free copper ions; plants take advantage of this fact by synthesizing metallic CuNPs through $\mathrm{Cu}^{2+}$ reduction in the rhizosphere [7]. In a study of hydroponic zucchini plant growth in the presence of CuNPs at $1000 \mathrm{mg} / \mathrm{L}$, Stampoulis and coworkers found that exposure to metallic CuNPs resulted in a slower rate of plant growth compared to the control. Interestingly, they found that $1000 \mathrm{mg} / \mathrm{L}$ of bulk $\mathrm{Cu}$ had approximately the same effect as $10 \mathrm{mg} / \mathrm{L} \mathrm{CuNO}_{3}$, and that $1000 \mathrm{mg} / \mathrm{L}$ of CuNPs had a similar effect as $100 \mathrm{mg} / \mathrm{L} \mathrm{CuNO}_{3}$ [8]. This provides further evidence that NPs do not have the same oxidative impact on plant growth as ionic micronutrients. Other metallic micronutrient NPs have shown similar results. At 2000 mg/L, zinc NPs almost completely inhibited root growth of radish, rape, ryegrass, lettuce, and cucumber seedlings with a lesser, but still significant, inhibition of corn seedling root growth [9]. This same study also investigated aluminum NPs, which only diminished root growth in corn, and showed no effect on the other plant seedlings [9]. More recently, Gao and coworkers [10] investigated the effects of CuO NP amendments (500 mg/kg) to wheat plants. They found that aging of CuO NP enhanced the NP toxicity due to enhanced dissolution during the growth period and affected the rhizosphere biochemical conditions such as $\mathrm{pH}$ and the production of root exudate. Du et al. [11] studied the effect of metallic CuNP (0-200 mg/kg) on the agronomical and physiological parameters of soil grown oregano. While all CuNP treatments decreased the content of starch and sugar in leaves, the biomass of roots and shoot was increased. They reported CuNPs did not exhibit significant toxicity in oregano.

While the direct impact of metal-based NPs on soil bacteria has not been extensively studied, CuNPs have been shown to affect the growth of common environmental bacteria including Escherichia coli and Staphylococcus aureus in a pure culture environment, especially at concentrations in excess of $2 \% w / w(20,000 \mathrm{mg} / \mathrm{kg})$ [12]. Although silver NPs are well-known for their toxicity to microorganisms [13-15], CuNPs were shown to impact the survival of the common environmental bacteria E. coli and Bacillus subtilis at slightly lower concentrations $(60 \mathrm{mg} / \mathrm{L})$ than AgNPs (70 mg/L) [16]. It has been documented that CuNPs are likely available to microorganisms in soil environments. A study by Kumar and coworkers documented a significant difference in substrate utilization compared to the control system by an arctic soil bacterial community when CuNPs were present at $66 \mathrm{mg} / \mathrm{kg}$, indicating a shift in the bacterial community even at this relatively low concentration. This change was not at marked as the change in substrate utilization caused by the same concentration of AgNPs [17]. The impacts of other nano-micronutrients have been poorly investigated. Aluminum NPs appeared to have minimal, if any, impact on the metabolic activity of Vibrio fischeri [18]. In a study of metal oxide NPs, both titanium dioxide and Zn oxide NPs negatively impacted the soil bacterial community of a grassland, as demonstrated through decreased genotype richness, substrate induced respiration, and extractable soil DNA over time periods up to 60 days [19]. These metal oxide NPs may induce more oxidative impacts than metallic, zero-valent metal NPs.

While these studies suggest both beneficial and toxicological effects of metal NPs, it remains difficult to extrapolate such results to evaluate the potential use of metal NPs as nanofertilizers since agricultural soils are often ignored in the most of laboratory studies. This study aims to investigate the effects of metallic CuNPs as a nanofertilizer component on the complex nitrogen cycle in agricultural soils. The nitrogen cycle in soil systems is essential to the growth of successful crop species. In particular, the nitrification process is of particular importance. In the objective of this study was to examine the effect of CuNPs to the soil nitrification kinetics using batch biogeochemical experiments. Metallic $\mathrm{Cu}(0) \mathrm{NPs}$ were chosen as a model $\mathrm{CuNP}$. One can expect that dissolution and sorption of CuNPs in soils that control the bioavailability of $\mathrm{Cu}$ to soil bacteria. For this reason, the dissolution experiments of CuNPs were performed in conjunction with adsorption isotherm experiments of $\mathrm{Cu}^{2+}(\mathrm{aq})$ and $\mathrm{CuNPs}$ onto soils. 


\section{Materials and Methods}

\subsection{Materials}

Fresh surface sandy loam soil from the Toccoa series (coarse-loamy, thermic typic Udifluvents) was used in this study, sourced from the Organic Farm in Clemson, South Carolina, USA. Soil was maintained at field capacity for nitrification experiments. For sorption experiments, soil was air dried and sieved to $2 \mathrm{~mm}$ prior to use. This soil was limed to $\mathrm{pH} 6.5$ based on exchangeable acidic cation content (i.e., $\mathrm{H}^{+}$and $\mathrm{Al}^{3+}$ ) prior to use and was maintained at field capacity. The near-neutral $\mathrm{pH}$ was chosen to facilitate the nitrification process. Physicochemical and mineralogical characterization of the soil is discussed in our previous work [13]. Briefly, the soil has a native cation exchange capacity of $7.4 \mathrm{cmol}_{\mathrm{c}} / \mathrm{kg}$, contains $1.5 \%$ organic matter, and has mineralogy dominated by quartz, kaolinite, hydroxyl interlayer vermiculite, gibbsite, hematite, and goethite. Metallic $\mathrm{Cu}(0)$ NPs (average particle size: $35 \mathrm{~nm}$, uncoated, \% purity: $99.6 \pm 0.2$, hydrodynamic diameter and zeta potential in $0.01 \mathrm{M} \mathrm{NaNO}_{3}$ at $\mathrm{pH}$ 6.2: $458 \pm 130.3 \mathrm{~nm}$ and $13.5 \pm 0.7 \mathrm{mV}$, respectively) were purchased from Nanostructured and Amorphous Materials, Inc. (Houston, TX, USA). For the following experiments, CuNP suspensions were freshly prepared for each use in a $2000 \mathrm{mg} / \mathrm{L}$ solution. They were immediately sonified at $25 \mathrm{kHz}$ for $30 \mathrm{~s}$ to ensure complete suspension of particles prior to its use. All reagents were prepared with ACS-grade chemicals (Sigma, St. Louis, MO, USA) and Milli-Q distilled, deionized water $(18.2 \mathrm{M} \Omega)$.

\subsection{Copper Nanoparticle Dissolution Experiments}

Dissolution of CuNPs was conducted under $0.01 \mathrm{M}$ ionic strength (I) using either $\mathrm{NaNO}_{3}$ or $\mathrm{Na}_{2} \mathrm{SO}_{4}$. To evaluate the ionic $\mathrm{Cu}$ toxicity, one should track the extent of $\mathrm{Cu}$ dissolution from the CuNP. The dissolution was assessed in these two electrolytes that were used in this study. It was to investigate the impact of nitrate (i.e., a product of nitrification) during the nitrification experiments. Sulfate was used as the background electrolyte for all analyses to prevent nitrate interference with nitrification analyses. Care was taken to ensure complete suspension of particles in the sample media, including a sonification of a fresh CuNP solution prior to each experiment. Copper NP concentrations ranged from 5 to $1000 \mathrm{mg} / \mathrm{L}$, and solutions were created from stock solutions described above. $\mathrm{pH}$ was maintained at $7 \pm 0.3$, and adjusted with $\mathrm{NaOH}$ when necessary. Dissolution experiments were conducted with the initial $\mathrm{Cu}$ concentration of 5,50, and $500 \mathrm{mg} / \mathrm{L}$ for $48 \mathrm{~h}$ in a batch mode. The dissolution reach pseudo-equilibrium after $48 \mathrm{~h}$. Samples were centrifuged at 28,600× $\mathrm{g}$ for $29 \mathrm{~min}$ to ensure settling of all solid $\mathrm{CuNPs}$ before samples were measured for $\mathrm{Cu}^{2+}$ concentration using an ion specific electrode (ISE) (Cole-Parmer, Vernon Hills, IL, USA). The detection limit of a cupric ISE was $0.09 \mathrm{mg} / \mathrm{L}$. Ion selective electrodes are known to drift if care is not taken in their storage, maintenance, and calibration. The quality assurance of ISE was performed by minimizing a drift ( $<3 \mathrm{mM} /$ day). The ISE was calibrated using a series of standards made from a $1000 \mathrm{mg} / \mathrm{L}$ standard (EMD Millipore, Burlington, MA, USA) before each measurement. Membranes were polished as needed, and maintained in an appropriate ISE storage solution. Samples were measured for $\left[\mathrm{Cu}^{2+}\right]$ immediately upon collection. Standard curves were limited to two orders of magnitude. The detection limit of the cupric ISE was $0.064 \mathrm{mg} / \mathrm{L}$. A separate set of dissolution experiments were also conducted under the same conditions in the presence of $20 \mathrm{mM}$ 3-Morpholino-2-hydroxypropanesulfonic acid (MOPSO) buffer used for the sorption experiments. Since many organic buffers contain active sites that could function as potential ligands for $\mathrm{Cu}^{2+}$, and since dissolution experiments maintained stable $\mathrm{pH}$ even without the addition of a buffer, the full suite of dissolution experiments was conducted without MOPSO. Adsorption of ionic $\mathrm{Cu}$ on the sidewall of the tubes was negligible (i.e., below the detection limit of Inductively coupled plasma atomic emission spectroscopy (ICP-AES) (SPECTRO Analytical Instruments Inc., Kleve, Germany) after the digestion). The adsorption of CuNPs on the sidewall was included for the final mass balance calculation. The CuNP adsorption on the sidewall of tubes was $\leq 0.5 \%$ of total CuNPs. 


\subsection{Copper Nanoparticle and $\mathrm{Cu}(\mathrm{II})(\mathrm{aq})$ Adsorption Experiments}

The sorption of whole CuNPs was tested on Toccoa soil in batch mode, using a ratio of $1 \mathrm{~g}$ soil to $20 \mathrm{~mL}$ solution with a reaction time of 2 days. Since the nitrification experiments were conducted in soil slurry, it was difficult to track the dissolved $\mathrm{Cu}$ and $\mathrm{CuNPs}$ because of the fast sorption reaction. To assess the adsorption capacity of soils, the batch adsorption experiments were conducted. Copper NPs were added at concentrations ranging from 5 to $1000 \mathrm{mg} / \mathrm{L}$. $\mathrm{pH}$ was maintained at 7 ( $\pm 0.3 \mathrm{pH}$ units) using $20 \mathrm{mM}$ 3-Morpholino-2-hydroxypropanesulfonic acid (MOPSO) buffer solution, and ionic strength was maintained at $0.01 \mathrm{M}$ using $\mathrm{Na}_{2} \mathrm{SO}_{4}$ salt. All tubes were shaken on an end-over shaker at $16 \mathrm{rpm}$. After $2 \mathrm{~d}$, solutions were centrifuged at $28,600 \times g$ for $29 \mathrm{~min}$. Stokes' Law was used to calculate this centrifugation time to ensure that larger soil particles would settle out of solution, but any free CuNPs would remain in solution. Aliquot samples were acidified with $\mathrm{HNO}_{3}$ prior to total $\mathrm{Cu}$ analysis using ICP-AES. Aliquots without acidification were also tested for potential dissolved $\mathrm{Cu}^{2+}$ using an ISE. The difference between total $\mathrm{Cu}$ and dissolved $\mathrm{Cu}^{2+}$ was used to evaluate the $\mathrm{CuNP}$ sorption. Because of the gradual dissolution of metallic CuNP during the nitrification experiments, sorption experiments of $\mathrm{Cu}^{2+}$ were also conducted under the same conditions. $\mathrm{Cu}$ (II) solutions such as $\mathrm{CuSO}_{4}$ were centrifuged at the same rate to maintain consistency and analyzed for $\left[\mathrm{Cu}^{2+}\right]$ and $[\mathrm{Cu}]$ total using both ISE and ICP-AES methods, respectively. In the final mass balance calculation, it was assured that there was a negligible contribution from the background $\mathrm{Cu}$ in soils. The ICP-AES analysis was performed by the Clemson University Agricultural Service Laboratory. This laboratory follows standard approved analytical methods and procedures, and has comprehensive quality assurance and quality control protocols [20]. A QCS-19 ICP 19 Element Quality Control Standard (High Purity Standards, Inc., Charleston, SC, USA) was used for the quality control. The detection limit of $\mathrm{Cu}$ in our sample matrix was $52 \mu \mathrm{g} / \mathrm{L}$.

\subsection{Batch Nitrification Kinetic Experiments}

The kinetic rate of nitrification was assessed through the oxygenated-shaken slurry method [21]. This slurry method was chosen because it is a well-accepted method in the soil science field and has been already demonstrated in the soil nitrification experiments using the same soil [22]. The maximum nitrification rate, $\left(V_{\max }\right)$, is determined over a 24 -h period. This value was used as an indicator to estimate the nitrification in these soils.

To maintain bacterial populations, a nutrient solution containing $1 \mathrm{mM} \mathrm{NH}_{4} \mathrm{H}_{2} \mathrm{PO}_{4}$ and $0.25 \mathrm{mM}$ $\left(\mathrm{NH}_{4}\right)_{2} \mathrm{SO}_{4}$ was created to ensure that $\mathrm{NH}_{4}{ }^{+}$was the limiting nutrient. This solution was maintained at an ionic strength of $0.01 \mathrm{M}$ using $\mathrm{Na}_{2} \mathrm{SO}_{4}$. Each sample was housed in a $125 \mathrm{~mL}$ Erlenmeyer flask. To each sample, $50 \mathrm{~mL}$ of the solution described above was added to $9 \mathrm{~g}$ soil, which had been limed and was maintained at field capacity. Copper NP flasks were dosed with the appropriate amount of freshly-prepared CuNP stock solution to achieve concentrations of 1, 10, or $100 \mathrm{mg} / \mathrm{L}$ CuNPs. Ionic $\mathrm{Cu}$ flasks were dosed with an appropriate amount of $1000 \mathrm{mg} / \mathrm{L} \mathrm{CuSO}_{4}$ as $\mathrm{Cu}^{2+}$ solution to achieve 1,10 , or $100 \mathrm{mg} / \mathrm{L}$ as $\left[\mathrm{Cu}^{2+}\right]$. Based on preliminary experiments, $100 \mathrm{mg} / \mathrm{L} \mathrm{Cu}^{2+}$ samples were not feasible as no nitrification was observed. Concentrations of $1 \mathrm{mg} / \mathrm{L} \mathrm{Cu}^{2+}$ were also avoided as this was not above the background concentration of copper in this soil. Each flask was sealed with vented Parafilm to allow gas exchange, and was placed on an orbital shaker at $180 \mathrm{rpm}$. This vigorous shaking maintained the oxygenated environment throughout the experiments. $10 \mathrm{~mL}$ samples were obtained at $2,4,22$, and $24 \mathrm{~h}$. At each sampling time, suspensions were centrifuged at $8000 \times g$ for $8 \mathrm{~min}$, and the supernatant frozen until nitrate analysis was conducted. Each condition was replicated a minimum of eight times to ensure accurate results.

Nitrate was analyzed through a salicylic acid colorimetric technique [23]. Subsamples of $0.80 \mathrm{~mL}$ held in $8 \mathrm{~mL}$ glass cuvettes were reacted with $0.32 \mathrm{~mL}$ of $5 \%$ salicylic acid dissolved in sulfuric acid, followed by $7.6 \mathrm{~mL}$ of $1.7 \mathrm{M} \mathrm{NaOH}$. After solutions cooled for $30 \mathrm{~min}$, they were measured for absorbance at $420 \mathrm{~nm}$ using a spectrophotometer, and concentration was determined using a 
standard curve. Based on solution volume and soil mass, concentrations were converted to units of $\mathrm{mg} \mathrm{N} / \mathrm{kg}$ soil.

\subsection{Statistical Analysis of Batch Nitrification Kinetic Experiments}

The $V_{\max }$ of each sample was determined from the linear regression analysis of nitrate concentration per $\mathrm{kg}$ soil per hour. An overall one-way analysis of variance was conducted to determine whether the variance between groups was greater than the variance within groups. To compare individual conditions, two-tailed $t$-tests were used to determine significant differences unless otherwise mentioned in the text.

\subsection{X-Ray Absorption near Edge Structure Spectroscopy (XANES) Analysis}

To better understand the changes in $\mathrm{Cu}$ speciation of $\mathrm{Cu}(0) \mathrm{NPs}$ in water and soils, XANES analysis was conducted at beamline X11A at National Synchrotron Light Source (NSLS), Upton, NY, USA. The monochromator consisted of two parallel Si (111) crystals with a vertical entrance slit of $0.4 \mathrm{~mm}$ and a horizontal entrance slit of $1 \mathrm{~cm}$. Using the CuNP dissolution method, freshly hydrated ( $\sim 3 \mathrm{~h}) \mathrm{CuNPs}$ in $0.1 \mathrm{M} \mathrm{NaNO}_{3}$ solutions were centrifuged and loaded on a mylar tape. A soil sample was prepared using the batch nitrification method (total $\mathrm{Cu}$ as CuNP: $500 \mathrm{mg} / \mathrm{kg}$ ). After 4 mo under oxic condition, a centrifuged soil sample was loaded on a polycarbonate sample holder covered with a $0.2 \mathrm{~mm}$ poly film on the front according to the method described in our previous work (Arai, 2011). The concentration was chosen to meet the detection limit (approximately $500 \mathrm{mg} / \mathrm{kg}$ ) of XAS measurements at a bending magnet BL X11A at NSLS. The incident X-ray beam was calibrated at 8979 $\mathrm{eV}$, the first inflection point of the first derivative peak of a $\mathrm{Cu}$ foil spectrum. The $\mathrm{Cu} \mathrm{K}$-edge XANES spectra were collected between 8900 and $9200 \mathrm{eV}$ in fluorescence mode at room temperature using a Ge13 detector. Reference spectra of $\mathrm{Cu}$ reference compounds $\left(\mathrm{Cu}(\mathrm{I})_{2} \mathrm{O}, \mathrm{Cu}(\mathrm{II}) \mathrm{O}\right.$, and $\left.\mathrm{Cu}(\mathrm{OH})_{2}\right)(\mathrm{Sigma}$, St. Louis, MO, USA) and unreacted $\mathrm{Cu}(0) \mathrm{NP}$ were also collected in transmission mode. All samples were loaded in a $\mathrm{N}_{2}$-filled glove bag right before the measurements. Two to three spectra were collected for each soil sample. No beam-induced reduction was observed during the measurements. The XAS data were normalized according to the method described in the previous work [24]. Because of the formation of insoluble $\mathrm{Cu}$ compounds, the XANES data were processed using the linear combination of reference compounds to fit the data range of 8920 to $9100 \mathrm{eV}$. In this analysis, the self-absorption correction function in SIXpack was used and no negative fit [25]. The energy shifts of reference compounds were not allowed during the fit.

\section{Results and Discussion}

\subsection{Copper Nanoparticle Dissolution Experiments}

A comparison of dissolution data in two electrolytes is shown in Figure 1. At low concentrations ( $<10 \mathrm{mg} / \mathrm{L})$, CuNPs displayed maximum dissolution of approximately $\sim 8 \%(0.4 \mathrm{mg} / \mathrm{L})$ under a sulfate background and approximately $4 \%(0.2 \mathrm{mg} / \mathrm{L})$ under nitrate background (Figure 1$)$. Under both nitrate and sulfate backgrounds, as the total concentration of CuNPs increases, the percent dissolved $\mathrm{Cu}$ decreases predictably. The small difference in dissolution extent between nitrate and sulfate backgrounds only shows a significant difference, as shown by a two-factor analysis of variance, at very high $[\mathrm{Cu}]_{\text {total }}(500 \mathrm{mg} / \mathrm{L})$ concentrations, although it is difficult to see in the \% dissolution axis. The sulfate background promoted CuNP dissolution to a greater extent $(\sim 0.9 \mathrm{mg} / \mathrm{L}$ dissolution) than the nitrate background ( $0.35 \mathrm{mg} / \mathrm{L}$ dissolution). The extent of CuNP dissolution is important because the release of $\mathrm{Cu}$ ions is associated with the production of reactive oxygen species as well as DNA damage in bacteria [26]. 


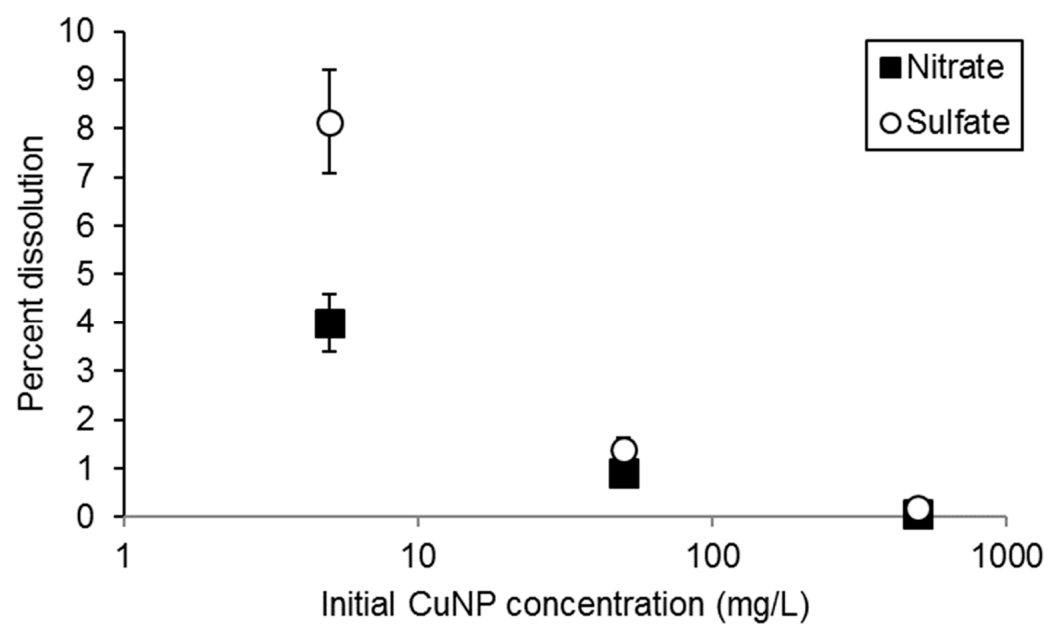

Figure 1. Copper nanoparticle dissolution with sodium nitrate or sodium sulfate background ions to $0.01 \mathrm{M}$ ionic strength. Error bars indicate one standard error above and below the mean. A two-factor analysis of variance indicated significant difference in percent dissolution across both electrolyte $(p=0.037)$ and initial CuNP concentration $(p<0.001)$.

It was found that the sulfate ion resulted in slightly heightened $\mathrm{Cu}^{2+}$ dissolution from CuNPs at very high $[\mathrm{Cu}]$ (Figure 1). A similar trend has been observed by other researchers. In a study of $\mathrm{CuO}$ microparticles $(<80 \mu \mathrm{m}), 0.5 \mathrm{M} \mathrm{H}_{2} \mathrm{SO}_{4}$ resulted in a higher kinetic rate of dissolution of the particles when compared to the same concentration of $\mathrm{HNO}_{3}$, and displayed a lower activation energy for dissolution [27]. With very high $[\mathrm{Cu}]$ in the $500 \mathrm{mg} / \mathrm{L} \mathrm{CuNP}$ experiments, it is likely that these effects are magnified. The effects of sulfate on CuNP dissolution could also be due to the higher affinity of $\mathrm{Cu}^{2+}$, a borderline acid on the hard/soft acid/base scale, for sulfur-containing compounds.

Copper and $\mathrm{CuO}$ NPs have been reported to have a wide range of dissolution values, indicating that the rate and extent of dissolution is impacted not only by the background ions of the solution, but also by a variety of particle-specific factors such as diameter, production quality, and initial amount of surface-sorbed $\mathrm{Cu}^{2+}$ [28]. For this reason, a careful analysis of CuNP sorption is essential in evaluating the toxicity to soil biota. A study by Griffitt et al. [29] found $25 \%$ dissolution of CuNPs (particle size: $80-450 \mathrm{~nm}$, specific surface area: $30.77 \mathrm{~m}^{2} / \mathrm{g}$ ) after $48 \mathrm{~h}$ at concentrations of $1.25 \mathrm{mg} / \mathrm{L}$ [29]. The pattern of diminished $\mathrm{Cu}^{2+}$ dissolution with increasing CuNP concentration was noted by Baek and An [30] while studying $\mathrm{CuO}$ and other metal oxide NPs, providing evidence of particle-specific factors, rather than simply dissolution, controlling NP toxicity [30]. The relatively low extent of dissolution of these CuNPs, in addition to their toxicity even at low concentrations suggests that the toxicity of these NPs may be due more to whole-particle effects rather than due to the evolution of $\mathrm{Cu}^{2+}$ ions from the surfaces of these particles, as also suggested by other researchers studying $\mathrm{CuO}$ NPs [30]. This is in contrast to the toxicity pattern displayed by silver NPs under both oxidizing and reducing conditions on the same soils studied here. The AgNPs appear to exhibit toxicity largely based on the amount of $\mathrm{Ag}^{+}$that is dissolved from their surfaces [13,22]. Overall, the CuNPs used in our sorption and nitrification experiments appear to be quite stable, compared to other commercially-available forms.

\section{2. $\mathrm{CuNP}$ and $\mathrm{Cu}^{2+}$ (aq) Sorption Experiments}

The results of the sorption experiments are shown in Figure 2, which quantifies the amount of $\mathrm{Cu}$ sorbed onto soil surfaces compared to the amount of total copper free in solution. All CuNP sorption samples (Figure 2a), when measured for $\mathrm{Cu}^{2+}$ on the ISE, were below the detection limit. The instrument was calibrated to measure concentrations as low as which is $0.0006 \mathrm{mg} / \mathrm{L}$. No plateau in CuNP sorption was reached through this experiment. The isotherm displays a nearly linear shape up to $C_{e q}=0.5 \mathrm{mg} / \mathrm{L}$, and the trend became a slightly nonlinear at $\mathrm{C}_{\mathrm{eq}}>0.5 \mathrm{mg} / \mathrm{L}$. 

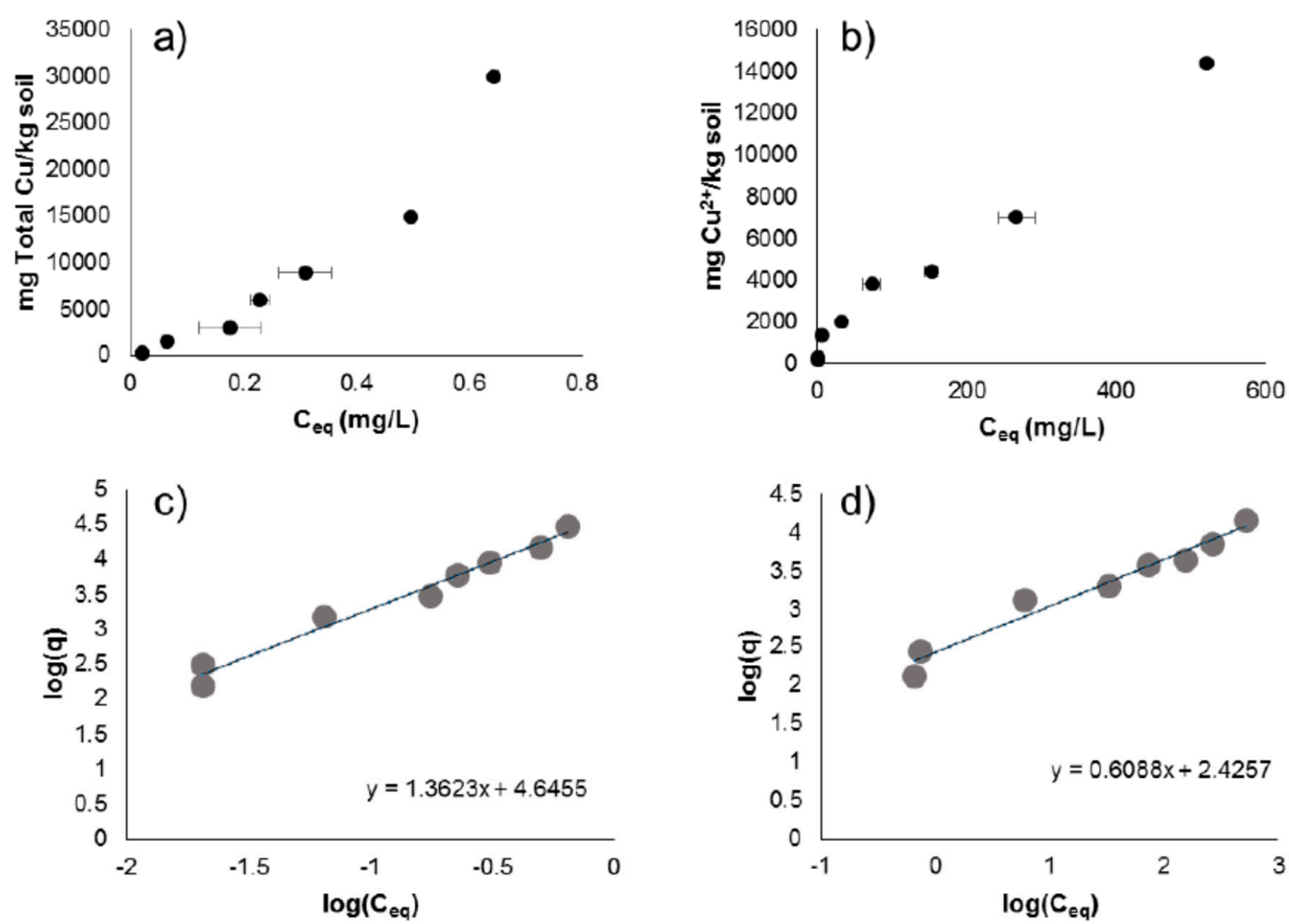

Figure 2. Sorption isotherms of (a) CuNPs and (b) $\mathrm{Cu}_{2+}$ as $\mathrm{Cu}(\mathrm{II}) \mathrm{SO} 4$ onto Toccoa soil. Error bars indicate one standard deviation above and below the Ceq value. Error bars indicating very small standard deviation values are obscured by data markers on some points. Freundlich models for (c) CuNPs and (d) $\mathrm{Cu}_{2+}$ as $\mathrm{Cu}(\mathrm{II}) \mathrm{SO}_{4}$ onto Toccoa soil estimate relative sorptive strength of copper species onto Toccoa soil.

Ionic $\mathrm{Cu}^{2+}$ displayed an S-curve isotherm, as shown in Figure $2 \mathrm{~b}$. Again, no plateau in $\mathrm{Cu}^{2+}$ sorption was reached through this experiment. Both sorption isotherms were modeled using the pseudo-equilibrium Freundlich model, as shown in Figure 2c,d, and quantified in Table 1. The affinity of CuNP for soil surfaces was extremely large as compared to the affinity of $\mathrm{Cu}^{2+}$ for soil surfaces, as indicated by the $K_{d}$ values for both.

Table 1. Freundlich equation isotherm parameters for Freundlich models shown in Figure $2 \mathrm{c}, \mathrm{d} . K_{d}$ indicated distribution constant for the adsorbent, calculated from the inverse log of the intercept. $n$ is the conversion factor, calculated from the inverse of the slope. $p$-values are calculated from the Fisher $\mathrm{F}$ statistic at $(1,6)$ degrees of freedom using the least squares method.

\begin{tabular}{ccccccc}
\hline Copper Species & Intercept & $\boldsymbol{K}_{\boldsymbol{d}}$ & Slope & $\boldsymbol{n}$ & $\mathbf{R}^{\mathbf{2}}$ & $\boldsymbol{p}$ \\
\hline $\mathrm{CuNP}$ & 4.646 & 44,210 & 1.362 & 0.7341 & 0.9782 & $<0.001$ \\
$\mathrm{Cu}(\mathrm{II}) \mathrm{SO}_{4}$ & 2.426 & 266.5 & 0.6088 & 1.642 & 0.9644 & $<0.001$ \\
\hline
\end{tabular}

In the presence of soils, the dissolution of CuNPs is different from what is experienced under more controlled aqueous conditions. While $\mathrm{Cu}^{2+}$ was measured in all sorption samples using an ISE, the concentration was below detection limit or ISE (detection limit $=0.0006 \mathrm{mg} / \mathrm{L} \mathrm{Cu}^{2+}$ ) or no significant concentration was present in soil solution. It is likely that dissolved $\mathrm{Cu}^{2+}$ from the CuNP surfaces was adsorbed in soils and or formation of insoluble compounds. In general, metallic NPs exhibit strong sorption onto soil surfaces, or indeed, any solid surface with which they come into contact $[13,31]$. For this reason, it was not surprising to see the strong sorption of CuNPs onto Toccoa soils (linear range $C_{\mathrm{eq}}$ up to $0.5 \mathrm{mg} / \mathrm{L}$ in Figure 2). A slightly nonlinear increase at $C_{\mathrm{eq}}>0.5 \mathrm{mg} / \mathrm{L}$ 
might indicate the aggregation of CuNPs in soil particles. In our previous AgNPs sorption investigation of the same soils, the high retention capacity of uncoated AgNPs in the same soils was attributed to the sorption of AgNP aggregates in soils [15].

In contrast to the CuNPs, $\mathrm{Cu}^{2+}$ displays moderate sorption in the soils (Figure 2 and Table 1). The beginnings of an S-shaped sorption isotherm displayed by $\mathrm{Cu}^{2+}$ onto the soil (Figure $2 \mathrm{~b}$ ) is common for $\mathrm{Cu}^{2+}$ ion onto mineral soil, as has been noted by other researchers, though it appears that we have not yet reached the sorptive capacity of $\mathrm{Cu}^{2+}$ onto this soil. This indicates that while the sorptive capacity of soil organic matter may have been reached, there are additional sites on the mineral components of the soil for $\mathrm{Cu}^{2+}$ sorption [32].

\subsection{XANES Analysis}

In order to better interpret the nitrification potential results below, XANES measurements were conducted to see the potential oxidation of $\mathrm{Cu}(0)$ during hydration and the nitrification experiments in soils. It is important to note that XAS spectra of soil without CuNPs were also taken using a GE 13 detector, and the results show negligible edge jump. This suggests that the spectra of CuNP reacted soil represent the $\mathrm{Cu}$ speciation of CuNPs in soils. Figure 3 and Table 2 show the results of LC fit XANES analysis of freshly hydrated $\mathrm{Cu}(0) \mathrm{NPs}$ and aged CuNPs in soils. The results of the LC fit were mainly contributed by $\mathrm{CuNPs}, \mathrm{Cu}(\mathrm{II}) \mathrm{O}$ and $\mathrm{Cu}(\mathrm{OH})_{2}$, but $\mathrm{Cu}(\mathrm{I})_{2} \mathrm{O} . \mathrm{CuSO}_{4}, \mathrm{CuCl}_{2}$, and $\mathrm{Cu}\left(\mathrm{NO}_{3}\right)_{2}$ (aq) were also considered in the fit, however, the fit excluded these fractions. It is clear that $\mathrm{Cu}(0) \mathrm{NPs}$ were contained $\mathrm{Cu}(\mathrm{I})$ prior to the hydration (vertical dashed line A in Figure 3). The NPs were further readily oxidized in $0.1 \mathrm{M} \mathrm{NaNO}_{3}$ to $\mathrm{Cu}(\mathrm{I})$ and $\mathrm{Cu}(\mathrm{II})$ forming oxide and hydroxide phases. Approximately $51 \%$ of the oxidized species were the original $\mathrm{CuNPs}$ followed by $\mathrm{Cu}(\mathrm{OH})_{2}, \mathrm{CuO}$, and $\mathrm{Cu}_{2} \mathrm{O}$. The partially oxidized CuNPs were further oxidized to $\mathrm{Cu}$ (II) in soils. After four months, only $39 \%$ of NPs remained, and the rest were $\mathrm{Cu}$ (II) species (a vertical line B in Figure 3).

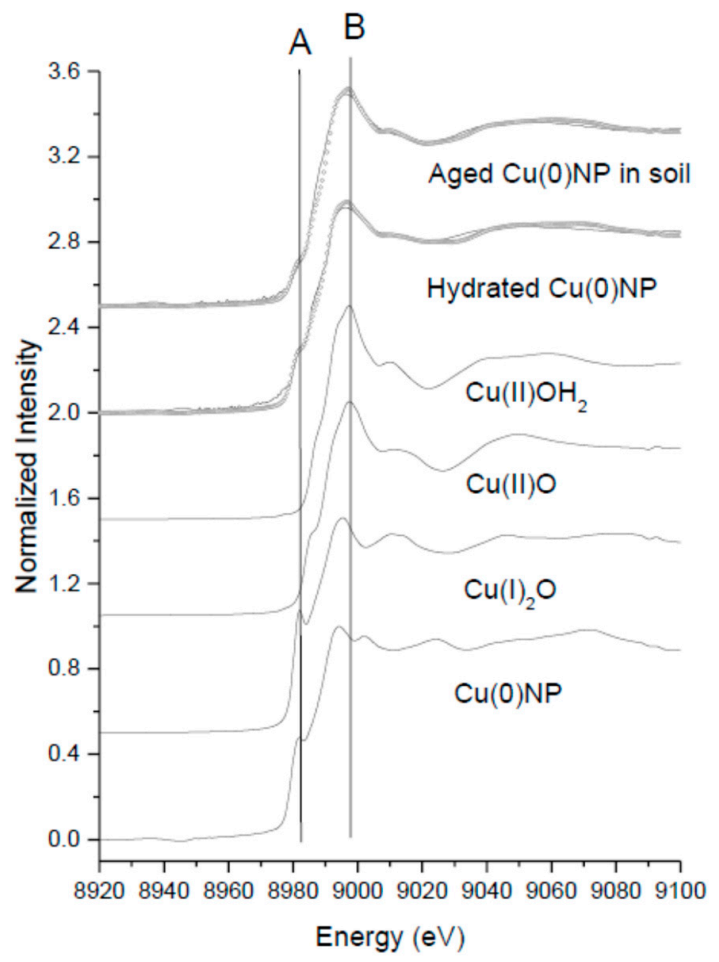

Figure 3. Bulk Cu K-edge NXAFS analysis of aged CuNP reacted soils and Cu reference compounds. Solid lines are normalized raw data and open circles are the fit if LC fit. The results are summarized in Table 2. Vertical lines (A) is aligned at $\sim 8983 \mathrm{eV}$ of the $\mathrm{Cu}(\mathrm{I})$ pre-edge peak corresponding to $1 \mathrm{~s}-4 \mathrm{p}$ transition. Vertical line (B) is aligned at the absorption peak of $\mathrm{Cu}(\mathrm{II}) \mathrm{O}$. 
Table 2. The results of linear combination of reference compound fit of $\mathrm{Cu} \mathrm{K}$ edge X-ray Absorption near Edge Structure Spectroscopy (XANES) spectra shown in Figure 3.

\begin{tabular}{|c|c|c|c|c|c|}
\hline \multirow{2}{*}{ Sample } & $\% \mathrm{Cu}(0) \mathrm{NP}$ & $\% \mathrm{Cu}(\mathrm{II}) \mathrm{O}$ & $\% \mathrm{Cu}(\mathrm{I})_{2} \mathrm{O}$ & $\% \mathrm{Cu}(\mathrm{OH})_{2}$ & Reduced Chi Square \\
\hline & \multicolumn{5}{|c|}{ Bulk XAS Analysis } \\
\hline Freshly hydrated $\mathrm{Cu}(0) \mathrm{NPs}$ & $51.19 \pm 0.5$ & $20.98 \pm 0.5$ & $22.4 \pm 0.5$ & $6 \pm 0.5$ & 0.00101 \\
\hline $4 \mathrm{mo}$ aged $\mathrm{Cu}(0) \mathrm{NPs}$ in soil & $39.04 \pm 0.7$ & $11.03 \pm 0.7$ & - & $52.3 \pm 0.7$ & 0.00063 \\
\hline
\end{tabular}

\subsection{Batch Nitrification Kinetic Experiments}

The results of a one-way ANOVA showed that the source of variance was largest between conditions, rather than within conditions $\left(p<10^{-10}\right)$. The variance of each condition is shown in Figure 4. Strong nitrification was observed in the control condition (Figure 5) along with a linear correlation between the concentration of nitrate as $\mathrm{N}$ and time, as documented by the high $\mathrm{R}^{2}$ value. Experimental conditions ranged from strong, linear nitrification, as in $1 \mathrm{mg} / \mathrm{L} \mathrm{Cu}^{2+}$ (Figure $6 \mathrm{~d}$ ) to a variable, nonlinear relationship between the concentration of nitrate as $\mathrm{N}$ and time, as in $100 \mathrm{mg} / \mathrm{L}$ $\mathrm{Cu}^{2+}$ (Figure 6f). Full results and $V_{\max }$ values are shown in Figure 6 and Table 3.

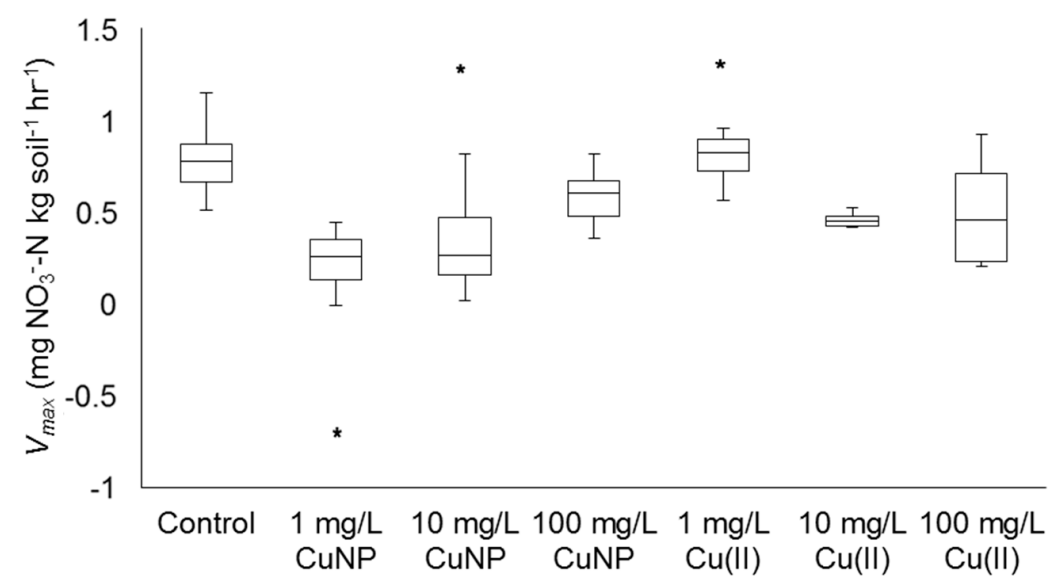

Figure 4. Analysis of variance of nitrification potential $\left(V_{\max }\right)$ for each batch nitrification condition. Plots indicate the first and third quartile values at the top and bottom of each box, respectively. Median of each condition is indicated by the line bisecting each box. Error bars indicate the maximum and minimum values within 1.5 times the interquartile range for each condition. Outlier values are indicated by the asterisk $\left({ }^{*}\right)$ symbol. Individual $V_{\max }$ values outside of this range are indicated by stars above or below the box for each condition.

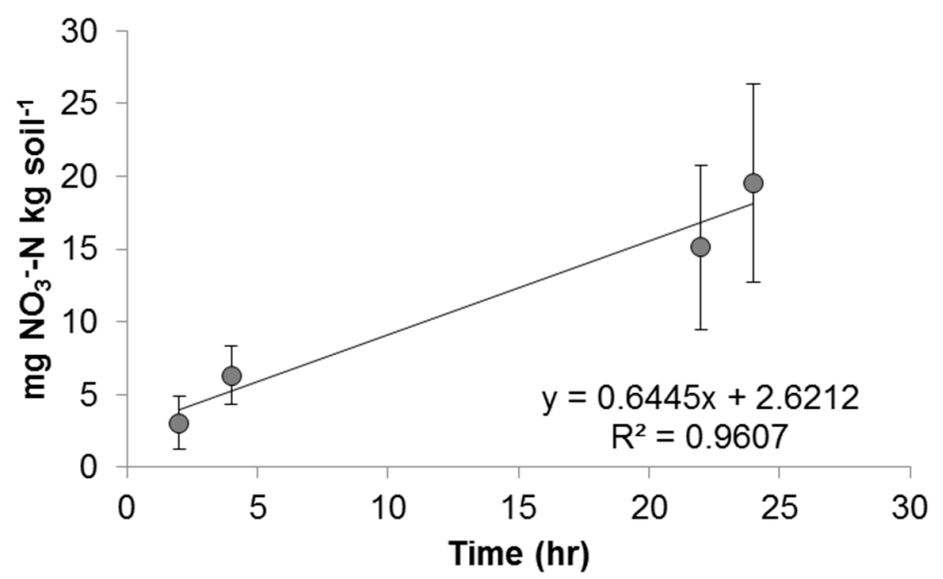

Figure 5. Nitrification kinetics for the control condition. The average $V_{\max }$ is indicated by the slope of the linear regression line, in this case, 0.6445 . 


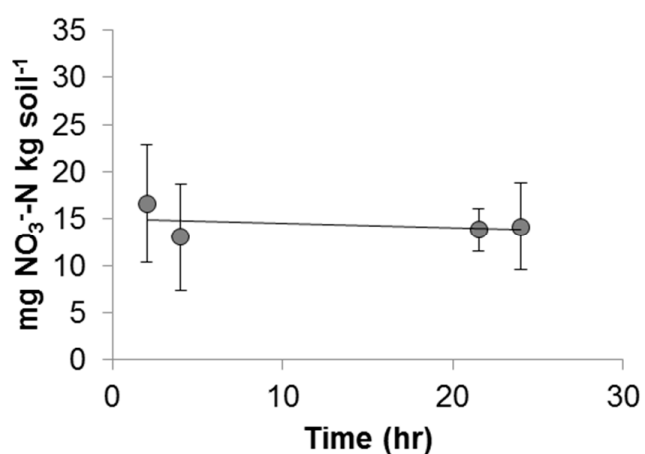

(a)

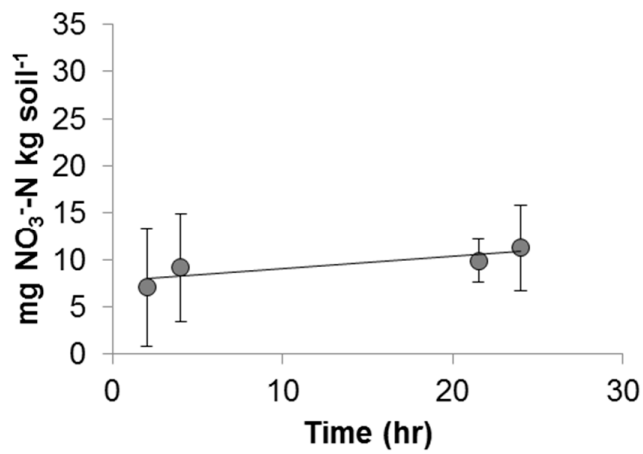

(b)

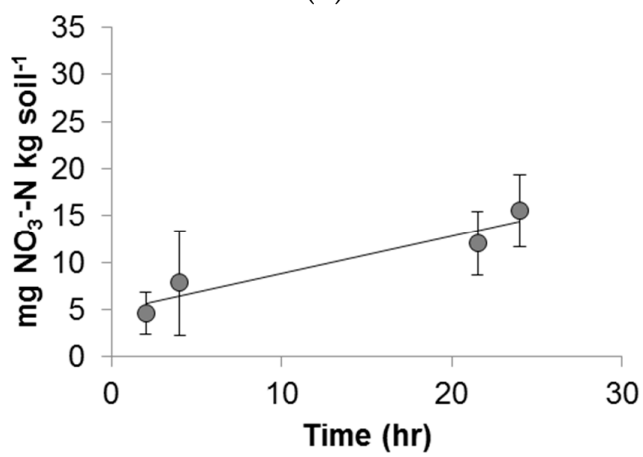

(c)

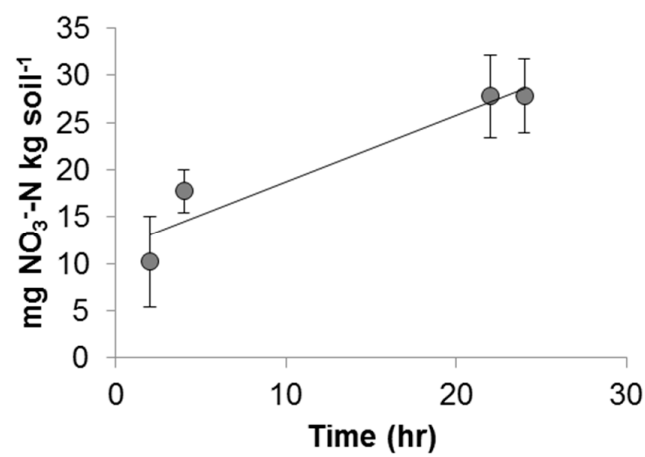

(d)

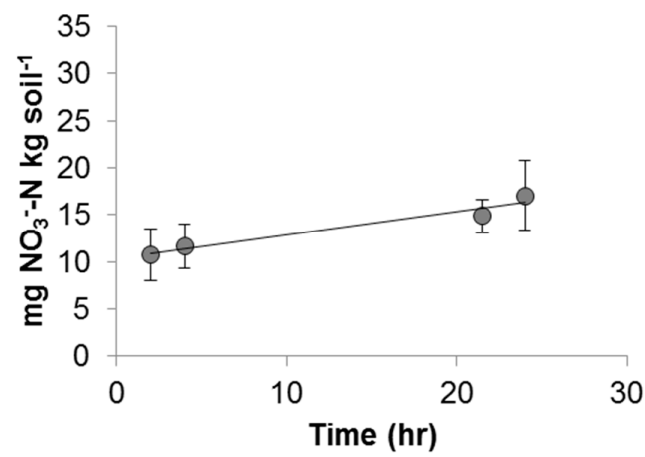

(e)

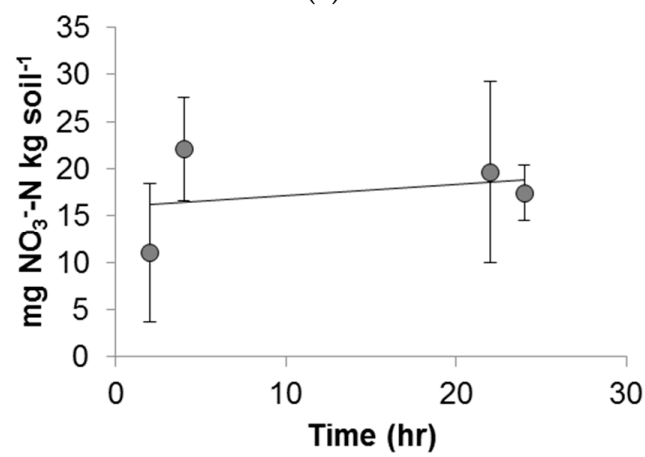

(f)

Figure 6. Nitrification kinetics in the presence of various $\mathrm{Cu}$ compounds: (a) $1 \mathrm{mg} / \mathrm{L} \mathrm{CuNPs}$; (b) $10 \mathrm{mg} / \mathrm{L} \mathrm{CuNPs;} \mathrm{(c)} 100 \mathrm{mg} / \mathrm{L}$ CuNPs; (d) $1 \mathrm{mg} / \mathrm{L} \mathrm{Cu}$ (II) sulfate as $\mathrm{Cu}^{2+}$; (e) $10 \mathrm{mg} / \mathrm{L} \mathrm{Cu}$ (II) sulfate as $\mathrm{Cu}^{2+}$; and (f) $100 \mathrm{mg} / \mathrm{L} \mathrm{Cu}$ (II) sulfate as $\mathrm{Cu}^{2+}$. Error bars indicate one standard deviation above and below the data point.

Table 3. Nitrification kinetics $V_{\max }$ and linear regression values for all conditions. $V_{\max }$ are displayed as \pm their standard deviation. $p$-values calculated from the Fisher F statistic at $(1,2)$ degrees of freedom using the least squares method.

\begin{tabular}{|c|c|c|c|c|c|}
\hline $\begin{array}{l}{[\mathrm{Cu}]_{\text {total }} \text { and } \mathrm{Cu}} \\
\text { Species }\end{array}$ & $\mathbf{N}$ & $\begin{array}{c}\text { Average } V_{\max }\left(\mathrm{mg} \mathrm{NO}_{3}-\mathrm{N}\right. \\
\left.\mathrm{kg} \mathrm{Soil}{ }^{-1} \mathrm{~h}^{-1}\right) \text { Value }\end{array}$ & $\begin{array}{l}\text { Average Intercept of } \\
\text { Linear Regression }\end{array}$ & $\begin{array}{c}\mathbf{R}^{2} \text { of Linear } \\
\text { Regression Line }\end{array}$ & $p$ \\
\hline Control & 17 & $0.645( \pm 0.190)$ & 2.62 & 0.961 & 0.020 \\
\hline $1 \mathrm{mg} / \mathrm{L} \mathrm{Cu}^{2+}$ & 9 & $0.703( \pm 0.236)$ & 11.7 & 0.908 & 0.045 \\
\hline $10 \mathrm{mg} / \mathrm{L} \mathrm{Cu}^{2+}$ & 8 & $0.247( \pm 0.0430)$ & 10.4 & 0.947 & 0.025 \\
\hline $100 \mathrm{mg} / \mathrm{L} \mathrm{Cu}^{2+}$ & 8 & $0.279( \pm 0.224)$ & 16.0 & 0.0837 & 0.683 \\
\hline $1 \mathrm{mg} / \mathrm{L} \mathrm{CuNP}$ & 12 & $-0.0489( \pm 0.205)$ & 15.1 & 0.132 & 0.580 \\
\hline $10 \mathrm{mg} / \mathrm{L} \mathrm{CuNP}$ & 20 & $0.132( \pm 0.347)$ & 7.68 & 0.757 & 0.135 \\
\hline $100 \mathrm{mg} / \mathrm{L}$ CuNP & 13 & $0.400( \pm 0.163)$ & 4.90 & 0.911 & 0.049 \\
\hline
\end{tabular}


Based on the ANOVA results, sources of variance between individual conditions were assessed using two-tailed $t$-tests. All $\mathrm{Cu}$ additions, with the exception of $1 \mathrm{mg} / \mathrm{L} \mathrm{Cu}^{2+}$, negatively impacted the ability of the native soil organisms to complete nitrification in this soil as compared to the control, $p<0.05$ (Figure 6, Table 4). Due to large variations in results, some conditions were repeated more than the standard eight times (i.e., control and $10 \mathrm{mg} / \mathrm{L} \mathrm{CuNP}$ ). Within the CuNP conditions, the $V_{\max }$ values of 1 and $10 \mathrm{mg} / \mathrm{L} \mathrm{CuNP}$ conditions were not significantly different from one another, while they were both significantly lower than the control (Table 4). Similarly, within the $\mathrm{Cu}^{2+}$ conditions, the $V_{\text {max }}$ values of 10 and $100 \mathrm{mg} / \mathrm{L} \mathrm{Cu}^{2+}$ did not significantly differ from one another but were both significantly lower than the control (Table 4). The $V_{\max }$ of $100 \mathrm{mg} / \mathrm{L} \mathrm{CuNP}$ was the highest of all of the CuNP conditions, significantly higher than that of the 1 or $10 \mathrm{mg} / \mathrm{L} \mathrm{CuNP}$ values. It was significantly lower, however, than the control $V_{\max }$ value. Amongst the CuNP conditions, $V_{\text {max }}$ increased as CuNP concentration increased. Within the $\mathrm{Cu}^{2+}$ conditions, $V_{\max }$ decreased as $\mathrm{Cu}^{2+}$ concentration increased.

Table 4. $p$-values from a $t$-test matrix of average kinetic rate $\left(V_{\max }\right)$ for each condition compared to one another. Squares marked " $x$ " indicate a duplicate $t$-test, and are not included.

\begin{tabular}{|c|c|c|c|c|c|c|}
\hline $\begin{array}{c}{[\mathrm{Cu}]_{\text {total }} \text { and } \mathrm{Cu}} \\
\text { Species }\end{array}$ & Control & $\begin{array}{l}1 \mathrm{mg} / \mathrm{L} \\
\mathrm{CuNP}\end{array}$ & $10 \mathrm{mg} / \mathrm{L} \mathrm{CuNP}$ & 100 mg/L CuNP & $\underset{\mathrm{Cu}^{2+}}{1 \mathrm{mg} / \mathrm{L}}$ & $10 \mathrm{mg} / \mathrm{L} \mathrm{Cu}^{2+}$ \\
\hline $1 \mathrm{mg} / \mathrm{L} \mathrm{CuNP}$ & 0.000285 & $x$ & $x$ & $x$ & $x$ & $x$ \\
\hline $10 \mathrm{mg} / \mathrm{L} \mathrm{CuNP}$ & $<0.0001$ & 0.0637 & $x$ & $x$ & $x$ & $x$ \\
\hline $100 \mathrm{mg} / \mathrm{L}$ CuNP & 0.00106 & 0.00255 & 0.00588 & $x$ & $x$ & $x$ \\
\hline $1 \mathrm{mg} / \mathrm{L} \mathrm{Cu}^{2+}$ & 0.534 & $<0.0001$ & $<0.0001$ & 0.00506 & $x$ & $x$ \\
\hline $10 \mathrm{mg} / \mathrm{L} \mathrm{Cu}^{2+}$ & $<0.0001$ & $<0.0001$ & 0.565 & 0.00227 & 0.00035 & $x$ \\
\hline $100 \mathrm{mg} / \mathrm{L} \mathrm{Cu}^{2+}$ & 0.0253 & 0.0424 & 0.382 & 0.382 & 0.0152 & 0.804 \\
\hline
\end{tabular}

\subsection{Impacts of $\mathrm{Cu}^{2+}$ and $\mathrm{CuNPS}$ on Soil Nitrification}

To evaluate the effect of CuNPs on the nitrification process, the effects of $\mathrm{Cu}^{2+}$ is first discussed because dissolved $\mathrm{Cu}^{2+}$ is a dissolution product of $\mathrm{CuNP}$ in soils. Because soil experiments generally exhibit some standard deviations in the results, the statistical analysis was carefully conducted using a large group of nitrification experiments. As the XANES analysis indicated, more than $50 \%$ of $\mathrm{Cu}$ in the NPs is present as $\mathrm{Cu}(\mathrm{II})$. At $1 \mathrm{mg} / \mathrm{L} \mathrm{Cu}^{2+}$, the rate of nitrification kinetics gradually (though not significantly) increased (Figures 5 and $6 \mathrm{~d}$, Table 3). This trend supports the importance of $\mathrm{Cu}$ as a micronutrient in soils. The nitrifiers were supplied with an essential micronutrient through this addition, instead of a toxicant. Low concentrations of $\mathrm{Cu}^{2+}$, under $10 \mathrm{mg} / \mathrm{L}$, have been shown to enhance microbial growth in activated sludge, a community with a strong component of nitrifying bacteria [33]. Copper has also been suggested to provide micronutrient levels of $\mathrm{Cu}^{2+}$ to bacteria at low concentrations [34].

However, the toxicity observed from $10 \mathrm{mg} / \mathrm{L} \mathrm{Cu}^{2+}$ was greater than would be expected from the literature values [35,36]. As shown in Table 3, soils treated with $10 \mathrm{mg} / \mathrm{L} \mathrm{Cu}^{2+}$ displayed a significantly lower $V_{\max }$ value than the control. At $100 \mathrm{mg} / \mathrm{L} \mathrm{Cu}^{2+}$, nitrification essentially stopped in some replications and continued at a significantly lower rate in others. This high variability is shown in the varied data shown in Figure $5 f$ and Table 3 . The low $\mathrm{R}^{2}$ value also indicates high variability and a potentially toxic condition, at least in some replications. This result is to be expected, as high concentrations likely pose toxicity to the vast majority of bacteria in the batch reactor $[35,36]$. Because of the high concentration, there is no statistical difference in $V_{\max }$ between 10 and $100 \mathrm{mg} / \mathrm{L} \mathrm{Cu}^{2+}$ (Table 4). To begin to impact the nitrification process, the $\mathrm{Cu}^{2+}$ concentration in the soil must be quite large. A 1948 study by Lees documented a 13\% inhibition of nitrification when a solution containing $64 \mathrm{mg} / \mathrm{L} \mathrm{Cu}^{2+}$ was percolated through the soil, also noting that $\mathrm{Cu}^{2+}$ showed some toxicity [35]. Similarly, in a more recent study, it was documented that $\mathrm{Cu}^{2+}$ required a relatively high concentration (above $250 \mathrm{mg} / \mathrm{kg}$ ) to cause at least half of the soil bacterial nitrifying community to be affected [36]. In summary, soils treated with $\geq 10 \mathrm{mg} / \mathrm{L} \mathrm{Cu}^{2+}$ displayed a significantly lower $V_{\max }$ value than the control. 
Through the course of the nitrification experiment, all CuNP conditions exhibited significantly lower $V_{\max }$ values than the control condition (Tables 3 and 4). The overall negative response of CuNPs is consistent with other observations in the literature (e.g., [34]). In this study, there is no statistical difference in $V_{\max }$ between CuNP 1 and $10 \mathrm{mg} / \mathrm{L}$ (Table 4); however, a significant statistical difference was observed between 10 and $100 \mathrm{mg} / \mathrm{L}$ systems (Table 4). Concentration independent effects were observed. Shah and Belozerova [5] investigated the impact of CuNPs, among other metallic NPs, on the overall soil microbes in situ, based on the microbial use of various substrates. They found that CuNPs negatively impacted the ability of microorganisms to utilize some commonly available substrates at concentrations of CuNPs as low as $130 \mathrm{mg} / \mathrm{kg}$.

Although we observe the variations in $V_{\text {max }}$ in the CuNP data with respect to the ionic Cu data, the statistical analysis (Table 4) showed that the toxicity of the CuNP is not statistically different from the respective concentration of the ionic $\mathrm{Cu}^{2+}$ system. With increasing the concentration of $\mathrm{CuNP}$, what is offsetting the similar toxicological response in the kinetic rate of nitrification, $V_{\text {max }}$ ? The concentration of dissolved $\mathrm{Cu}^{2+}$ is always greater, though nearly all $\mathrm{Cu}$ ions undergo adsorption in soils, in the ionic $\mathrm{Cu}$ systems compared to the respective CuNP system. The reasonable explanation is the potential production of reactive oxygen species (ROS) from CuNP. Surface oxidation-enhanced ROS production has been reported by several researchers [26,37]. Although the detection of ROS was difficult in our soil slurry systems because of interference from dissolved organics and other ions in soil filtrates, ROS via the surface oxidation of CuNP cannot be ignored. This could explain the similar suppressed $V_{\max }$ among the same concentration of $\mathrm{Cu}^{2+}$ and $\mathrm{CuNP}$.

\section{Conclusions}

This study evaluated the effects of metallic CuNPs as a nanofertilizer on the soil nitrification process. One of the primary drivers for investigating the use of nanoscale $\mathrm{Cu}$ is to increase micronutrient delivery and uptake efficacy without causing the negative impact on the soil nutrient cycles. While CuNPs sorb strongly to soils, they showed negative effects on nitrification kinetics between 1 and $100 \mathrm{mg} / \mathrm{L}$. As evident in the XANES analysis, the metallic Cu(0)NP readily oxidized to $\mathrm{Cu}(\mathrm{II})$-oxide and -hydroxides with increasing aging time under oxic condition. The dissolution of $\mathrm{Cu}^{2+}$ as well as potential ROS production could explain the suppressed nitrification kinetic rate. The window of $\left[\mathrm{Cu}^{2+}(\mathrm{aq})\right]$ for beneficial effects as a constituent in soil nitrifier seems very small. The results suggest the delivery of $\mathrm{Cu}$-incorporated nanofertilizer must be carefully evaluated with respect to its trace metal toxicity to microorganisms in various agricultural soils.

Author Contributions: Y.A. and A.R.V. conceived and designed the experiments; A.R.V. performed macroscopic experiments and analyzed the data; Y.A. performed the XAS measurements and analyzed the data; Y.A. and A.R.V. wrote and revised the paper; All authors read and approved the manuscript.

Funding: This research was funded the USDA National Institute of Food and Agriculture, hatch project grant number 875-939.

Acknowledgments: This work at X11A is supported by the U.S. DOE, Office of Science, Office of Basic Energy Sciences, under contract no. DE-AC02-98CH10886. Use of the NSLS was supported by the U.S. Department of Energy, Office of Science, Office of Basic Energy Sciences, under Contract No. DE-AC02-98CH10886.

Conflicts of Interest: The authors declare no conflicts of interest.

\section{Abbreviations}

CuNP Copper nanoparticles

ICP-AES Inductively coupled plasma atomic emission spectroscopy

ISE Ion selective electrode

MOPSO 3-Morpholino-2-hydroxypropanesulfonic acid

NP nanoparticles

XAS X-ray absorption spectroscopy 


\section{References}

1. DeRosa, M.C.; Monreal, C.; Schnitzer, M.; Walsh, R.; Sultan, Y. Nanotechnology in fertilizers. Nat. Nanotechnol. 2010, 5, 91. [CrossRef] [PubMed]

2. Liu, X.-M.; Feng, Z.-B.; Zhang, F.-D.; Zhang, S.-Q.; He, X.-S. Preparation and Testing of Cementing and Coating Nano-Subnanocomposites of Slow/Controlled-Release Fertilizer. Agric. Sci. China 2006, 5, 700-706. [CrossRef]

3. Ray, S.K.; Varadachari, C.; Ghosh, K. Novel Slow-Releasing Micronutrient Fertilizers. 2. Copper Compounds. J. Agric. Food Chem. 1997, 45, 1447-1453. [CrossRef]

4. Barden, J.A.; Halfacre, R.G.; Parrish, D.J. Plant Science; McGraw-Hill: New York, NY, USA, 1987.

5. Shah, V.; Belozerova, I. Influence of metal nanoparticles on the soil microbial community and germination of lettuce seeds. Water Air Soil Pollut. 2009, 197, 143-148. [CrossRef]

6. Lee, W.-M.; An, Y.-J.; Yoon, H.; Kweon, H.-S. Toxicity and bioavailability of copper nanoparticles to the terrestrial plants mung bean (Phaseolus radiatus) and wheat (Triticum aestivum): Plant agar test for water-insoluble nanoparticles. Environ. Toxicol. Chem. 2008, 27, 1915-1921. [CrossRef] [PubMed]

7. Manceau, A.; Nagy, K.L.; Marcus, M.A.; Lanson, M.; Geoffroy, N.; Jacquet, T.; Kirpichtchikova, T. Formation of metallic copper nanoparticles at the soil-root interface. Environ. Sci. Technol. 2008, 42, 1766-1772. [CrossRef] [PubMed]

8. Stampoulis, D.; Sinha, S.K.; White, J.C. Assay-dependent phytotoxicity of nanoparticles to plants. Environ. Sci. Technol. 2009, 43, 9473-9479. [CrossRef] [PubMed]

9. Lin, D.; Xing, B. Phytotoxicity of nanoparticles: Inhibition of seed germination and root growth. Environ. Pollut. 2007, 150, 243-250. [CrossRef] [PubMed]

10. Gao, X.; Avellan, A.; Laughton, S.; Vaidya, R.; Rodrigues, S.M.; Casman, E.A.; Lowry, G.V. CuO Nanoparticle Dissolution and Toxicity to Wheat (Triticum aestivum) in Rhizosphere Soil. Environ. Sci. Technol. 2018, 52, 2888-2897. [CrossRef] [PubMed]

11. Du, W.C.; Tan, W.J.; Yin, Y.; Ji, R.; Peralta-Videa, J.R.; Guo, H.Y.; Gardea-Torresdey, J.L. Differential effects of copper nanoparticles/microparticles in agronomic and physiological parameters of oregano (Origanum vulgare). Sci. Total Environ. 2018, 618, 306-312. [CrossRef] [PubMed]

12. Cioffi, N.; Torsi, L.; Ditaranto, N.; Tantillo, G.; Ghibelli, L.; Sabbatini, L.; Bleve-Zacheo, T.; D'Alessio, M.; Zambonin, P.G.; Traversa, E. Copper Nanoparticle/Polymer Composites with Antifungal and Bacteriostatic Properties. Chem. Mater. 2005, 17, 5255-5262. [CrossRef]

13. VandeVoort, A.R.; Arai, Y. Effect of silver nanoparticles on soil denitrification kinetics. Ind. Biotechnol. 2012, 8, 358-364. [CrossRef]

14. VandeVoort, A.R.; Skipper, H.; Arai, Y. Macroscopic assessment of nanosilver toxicity to soil denitrification Kinetics. J. Environ. Qual. 2014, 43, 1424-1430. [CrossRef] [PubMed]

15. VandeVoort, A.R.; Tappero, R.; Arai, Y. Residence time effects on phase transformation of nanosilver in reduced soils. Environ. Sci. Pollut. Res. 2014, 21, 7828-7837. [CrossRef] [PubMed]

16. Yoon, K.-Y.; Hoon Byeon, J.; Park, J.-H.; Hwang, J. Susceptibility constants of Escherichia coli and Bacillus subtilis to silver and copper nanoparticles. Sci. Total Environ. 2007, 373, 572-575. [CrossRef] [PubMed]

17. Kumar, N.; Shah, V.; Walker, V.K. Perturbation of an arctic soil microbial community by metal nanoparticles. J. Hazard. Mater. 2011, 190, 816-822. [CrossRef] [PubMed]

18. Doshi, R.; Braida, W.; Christodoulatos, C.; Wazne, M.; O'Connor, G. Nano-aluminum: Transport through sand columns and environmental effects on plants and soil communities. Environ. Res. 2008, 106, 296-303. [CrossRef] [PubMed]

19. Ge, Y.; Schimel, J.P.; Holden, P.A. Evidence for negative effects of $\mathrm{TiO}_{2}$ and $\mathrm{ZnO}$ nanoparticles on soil bacterial communities. Environ. Sci. Technol. 2011, 45, 1659-1664. [CrossRef] [PubMed]

20. Sikora, F.J.; Moore, K.P. Soil Test Methods from the Southeastern United States; Southern Cooperative Series Bulletin No. 419; Southern Extension and Research Activity Information Exchange Group 6 (SERA-IEG-6): Athens, GA, USA, 2014; ISBN 1-58161-419-5.

21. Hart, S.C.; Stark, J.M.; Davidson, E.A.; Firestone, M.K. Nitrogen Mineralization, Immobilization, and Nitrification. In Methods of Soil Analysis, Part 2. Microbiological and Bio-Chemical Properties; Weaver, R., Angle, S., Bottomley, P., Bezdicek, D., Smith, S., Tabatabai, A., Wollum, A., Eds.; Soil Science Society of America: Madison, WI, USA, 1994. 
22. Masrahi, A.; VandeVoort, A.R.; Arai, Y. Effects of silver nanoparticle on soil-nitrification processes. Arch. Environ. Contam. Toxicol. 2014, 66, 504-513. [CrossRef] [PubMed]

23. Cataldo, D.A.; Maroon, M.; Schrader, L.E.; Youngs, V.L. Rapid colorimetric determination of nitrate in plant tissue by nitration of salicylic acid. Commun. Soil Sci. Plant Anal. 1975, 6, 71-80. [CrossRef]

24. Arai, Y. Aqueous interfacial chemistry of kaolinite for the removal of $\mathrm{Cu}(\mathrm{II})$ in the presence of birnessite: Kinetics and spectroscopic studies. Appl. Clay Sci. 2011, 53, 572-580. [CrossRef]

25. Webb, S.M. SIXpack: A graphical user interface for XAS analysis using IFEFFIT. Phys. Scr. 2005, T115, 1011-1014. [CrossRef]

26. Bondarenko, O.; Ivaska, A.; Käkinen, A.; Kahru, A. Sub-toxic effects of CuO nanoparticles on bacteria: Kinetics, role of $\mathrm{Cu}$ ions and possible mechanisms of action. Environ. Pollut. 2012, 169, 81-89. [CrossRef] [PubMed]

27. Habbache, N.; Alane, N.; Djerad, S.; Tifouti, L. Leaching of copper oxide with different acid solutions. Chem. Eng. J. 2009, 152, 503-508. [CrossRef]

28. Misra, S.K.; Dybowska, A.; Berhanu, D.; Luoma, S.N.; Valsami-Jones, E. The complexity of nanoparticle dissolution and its importance in nanotoxicological studies. Sci. Total Environ. 2012, 438, 225-232. [CrossRef] [PubMed]

29. Griffitt, R.J.; Weil, R.; Hyndman, K.A.; Denslow, N.D.; Powers, K.; Taylor, D.; Barber, D.S. Exposure to Copper Nanoparticles Causes Gill Injury and Acute Lethality in Zebrafish (Danio rerio). Environ. Sci. Technol. 2007, 41, 8178-8186. [CrossRef] [PubMed]

30. Baek, Y.-W.; An, Y.-J. Microbial toxicity of metal oxide nanoparticles $\left(\mathrm{CuO}, \mathrm{NiO}, \mathrm{ZnO}\right.$, and $\left.\mathrm{Sb}_{2} \mathrm{O}_{3}\right)$ to Escherichia coli, Bacillus subtilis, and Streptococcus aureus. Sci. Total Environ. 2011, 409, 1603-1608. [CrossRef] [PubMed]

31. Darlington, T.K.; Neigh, A.M.; Spencer, M.T.; Guyen, O.T.N.; Oldenburg, S.J. Nanoparticle characteristics affecting environmental fate and transport through soil. Environ. Toxicol. Chem. 2009, 28, 1191-1199. [CrossRef] [PubMed]

32. Sposito, G. The Chemistry of Soils, 2nd ed.; Oxford University Press: New York, NY, USA, 2008.

33. Cabrero, A.; Fernandez, S.; Mirada, F.; Garcia, J. Effects of copper and zinc on the activated sludge bacteria growth kinetics. Water Res. 1998, 32, 1355-1362. [CrossRef]

34. Raffi, M.; Mehrwan, S.; Bhatti, T.M.; Akhter, J.I.; Hameed, A.; Yawar, W.; ul Hasan, M.M. Investigations into the antibacterial behavior of copper nanoparticles against Escherichia coli. Ann. Microbiol. 2010, 60, 75-80. [CrossRef]

35. Lees, H. The effects of zinc and copper on soil nitrification. Biochem. J. 1948, 42, 534-538. [CrossRef] [PubMed]

36. Fait, G.; Broos, K.; Zrna, S.; Lombi, E.; Hamon, R. Tolerance of nitrifying bacteria to copper and nickel. Environ. Toxicol. Chem. 2006, 25, 2000-2005. [CrossRef] [PubMed]

37. Shi, M.; Kwon, H.S.; Peng, Z.; Elder, A.; Yang, H. Effects of surface chemistry on the generation of reactive oxygen species by copper nanoparticles. ACS Nano 2012, 27, 2157-2164. [CrossRef] [PubMed] 